\title{
Spektrofotometri dengan Pendekatan Kemometrika untuk Analisis Asam Benzoat dan Asam Salisilat Secara Simultan dalam Sediaan Larutan
}

\author{
Curie Julia Kulzumia, Dina Qoyima, Hendri Wasito, Sri Sutji Susilowati
}

Jurusan Farmasi, Fakultas IImu Kesehatan, Universitas Jenderal Soedirman

Korespondensi: Hendri Wasito

Email: hendri.apt@gmail.com

\begin{abstract}
ABSTRAK: Kombinasi asam benzoat (AB) dan asam salisilat (AS) memiliki fungsi sebagai fungistatik danfungisida. Salah satu bentuksediaan farmasi yangmengandungkedua senyawa tersebut adalah dalam bentuk larutan. Penelitian ini bertujuan untuk mengembangkan, memvalidasi, dan mengaplikasikan spektrofotometri dengan pendekatan kemometrika untuk analisis AB dan AS dalam sediaan larutan secara simultan. Model kemometrika yang digunakan adalah analisis multivariat principal component regression (PCR) dan partial least square-1 (PLS-1) yang dikembangkan menggunakan 16 training set dan 10 test set. Konsentrasi AB dan AS yang digunakan secara berurutan antara 2,0-8,0 $\mu \mathrm{g} / \mathrm{mL}$ dan 3,0-12,0 $\mu \mathrm{g} / \mathrm{mL}$. Absorbansi larutan diukur dengan spektrofotometer pada panjang gelombang 200-400 nm, dan selanjutnya diolah dengan model PCR dan PLS-1 menggunakan program analisis multivariat Unscrambler ${ }^{\circledR}$. Validasi metode analisis yang dievaluasi meliputi linearitas, rentang, akurasi, presisi, limit of detection (LOD), dan limit of quantification (LOQ). Hasil penelitian didapatkan panjang gelombang optimum untuk $\mathrm{AB}$ dan $\mathrm{AS}$ berturut-turut adalah 225$235 \mathrm{~nm}$ dan 235-245 nm. Principal components (PCs) yang digunakan pada pengukuran AB dan AS dengan model PCR adalah 1 dan 3 sedangkan model PLS-1 adalah 2 dan 4. Metode yang dikembangkan telah divalidasi dan dapat diaplikasikan pada sediaan larutan yang mengandung AB dan AS.
\end{abstract}

Kata kunci: asam benzoat; asam salisilat; kemometrika; validasi

\begin{abstract}
The combination of benzoic acid (AB) and salicylic acid (AS) has an pharmacological effect as fungistatic and fungicide. Pharmaceutical preparation containing both compounds is in the form of a solution. The aim of this research is to develop, validate, and apply chemometrics assisted spectrophotometry to determine $A B$ and $A S$ simultaneously in solution preparation. The chemometrics model used were multivariate analysis of principal component regression (PCR) and partial least square-1 (PLS-1) that developed using 16 training sets and 10 test sets. The AB and AS range concentrations used were from $2.0-8.0 \mu \mathrm{g} / \mathrm{mL}$ and 3.0-12.0 $\mu \mathrm{g} / \mathrm{mL}$, respectively. The absorbance of the solution was measured by a spectrophotometer at a wavelength of 200-400 $\mathrm{nm}$, and then performed with PCR and PLS-1 models using an Unscrambler@ multivariate analysis program. Method validation evaluated include linearity, range, accuracy, precision, limit of detection (LOD), and limit of quantification (LOQ). The result of the research shows that the optimum wavelength for $A B$ and $A S$ are 225-235 $\mathrm{nm}$ and 235-245 $\mathrm{nm}$, respectively. Principal components (PCs) used in $A B$ and $A S$ measurements with PCR models are 1 and 3 whereas the PLS-1 model is 2 and 4. The developed method has been validated and can be applied to determine AB and AS simultaneously in solution preparations.
\end{abstract}

Keywords: benzoic acid; salicylic acid; chemometrics; validation 


\section{Pendahuluan}

Kombinasi sediaan asam benzoat (AB) dan asam salisilat (AS) telah beredar di pasaran dalam bentuk sediaan larutan. $A B$ dapat menghambat aktivitas jamur dan AS berfungsi sebagai keratolitik yang dapat meningkatkan absorbsi obat atau zat aktif di kulit [1]. Struktur kimia kedua senyawa tersebut dapat dilihat pada Gambar 1.
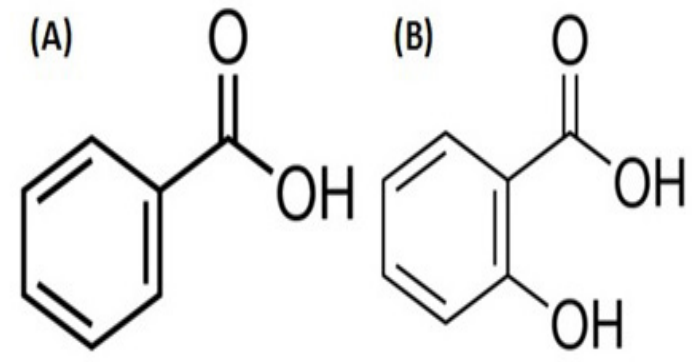

Gambar 1. Struktur kimia (A) asam benzoat dan (B) asam salisilat

Analisis keberadaan senyawa AB dan AS dalam sediaan farmasiyangtelah dilaporkan diantaranya adalah dengan metode solid phase extraction (SPE) dan high performance liquid chromatography (HPLC) [2], first derivative spectrophotometry [3, 4], gas chromatography (GC) [5], dan micellar electrocinetic chromatography [6, 7].

Metode spektrofotometri dapat digunakan untuk menganalisis $\mathrm{AB}$ dan $\mathrm{AS}$ dalam sediaan farmasi karena kedua senyawa ini memiliki gugus kromofor namun kedua senyawa tersebut memiliki pola spektra UV yang saling tumpang tindih, sehingga campuran kedua senyawa tersebut tidak dapat diukur secara simultan menggunakan spektrofotometri konvensional atau zero order. Pengukuran suatu campuran yang memiliki spektra serapan yang tumpang tindih akan mengakibatkan hasil pengukuran kurang akurat [8]. Pendekatan lainnya yang dapat digunakan dalam analisis kedua senyawa ini adalah dengan teknik kemometrika. Kemometrika merupakan metode kalibrasi multivariat yang telah banyak dikembangkan untuk menganalisis dua atau lebih senyawa secara simultan dengan profil spektra yang saling tumpang tindih [9].

Spektrofotometri dengan pendekatan kemometrika principal component regression (PCR) dan partial least square-1 (PLS-1) merupakan contoh model kalibrasi multivariat yang sering digunakan dalam analisis senyawa campuran secara simultan [10]. Penggunaan metode spektrofotometri dengan pendekatan kemometrika PCR dan PLS-1 pada penetapan kadar senyawa obat anti fungi AB dan AS secara simultan dalam bentuk sediaan larutan belum pernah dilaporkan. Oleh karena itu, penelitian ini dilakukan untuk mengembangkan dan melakukan validasi metode spektrofotometri dengan pendekatan kemometrika PCR dan PLS-1 dalam penetapan kadar campuran kedua senyawa tersebut dalam sediaan farmasi berupa larutan.

\section{Metode Penelitian}

\subsection{Bahan dan instrumen}

Bahan-bahan yang digunakan dalam penelitian adalah $\mathrm{HCl}$ 37\% pro analysis (E.Merck, Darmstadt, Germany), asam benzoat pro analysis (E.Merck, Darmstadt, Germany), asam salisilat pro analysis (E.Merck, Darmstadt, Germany), sediaan larutan (kalpanax $\left.{ }^{\circledR}\right)$, dan aquades, sedangkan alat yang digunakan dalam penelitian adalah spektrofotometer UV/Vis-1800 double beam (Shimadzu Corporation, Kyoto, Jepang) dengan kuvet quartz $1 \mathrm{~cm}$. Program analisis multivariat yang digunakan adalah Unscrambler ${ }^{\circledR}$ X 10.4 (bit.64) (Camo, Oslo, Norwey).

\subsection{Prosedur penelitian}

\subsubsection{Pembuatan larutan stok dan larutan campuran asam benzoat dan asam silsilat}

Larutan stok dibuat dengan menimbang seksama senyawa standar $\mathrm{AB}$ dan $\mathrm{AS}$ masingmasing $50 \mathrm{mg}$ dan dilarutkan dalam $\mathrm{HCl} 0,1$ $\mathrm{N}$ hingga didapatkan konsentrasi larutan stok $1000 \mu \mathrm{g} / \mathrm{mL}$. Konsentrasi larutan campuran yang digunakan berkisar antara 2,0-8,0 $\mu \mathrm{g} / \mathrm{mL}$ untuk $\mathrm{AB}$ dan 3,0-12,0 $\mu \mathrm{g} / \mathrm{mL}$ untuk AS dengan pelarut larutan $\mathrm{HCl} 0,1 \mathrm{~N}$. 
Tabel 1. Komposisi training set dan test set

\begin{tabular}{lllll}
\hline \multirow{2}{*}{$\begin{array}{l}\text { Larutan } \\
\text { Campuran }\end{array}$} & Training Set & \multicolumn{3}{c}{ Test Set } \\
\cline { 2 - 5 } & AB $(\boldsymbol{\mu g} / \mathbf{m L})$ & AS $(\boldsymbol{\mu g} / \mathbf{m L})$ & AB $(\boldsymbol{\mu g} / \mathbf{m L})$ & AS $(\boldsymbol{\mu g} / \mathbf{m L})$ \\
\hline 1 & 1,9 & 7,2 & 7,0 & 4,8 \\
2 & 7,8 & 7,2 & 5,3 & 3,4 \\
3 & 4,9 & 2,9 & 4,7 & 6,0 \\
4 & 4,9 & 11,5 & 6,3 & 5,7 \\
5 & 3,5 & 4,3 & 5,8 & 4,8 \\
6 & 3,5 & 10,4 & 4,4 & 7,6 \\
7 & 6,1 & 4,3 & 3,9 & 5,2 \\
8 & 6,1 & 10,4 & 2,5 & 6,9 \\
9 & 4,9 & 7,2 & 2,9 & 8,6 \\
10 & 4,9 & 7,2 & 7,3 & 9,6 \\
11 & 4,9 & 7,2 & & \\
12 & 4,9 & 7,2 & & \\
13 & 4,9 & 7,2 & & \\
14 & 4,9 & 7,2 & & \\
15 & 4,9 & 7,2 & & \\
16 & 4,9 & 7,2 & & \\
\hline
\end{tabular}

\subsubsection{Penentuan profil serapan UV asam benzoat dan asam salisilat}

Penentuan profil serapan UV dilakukan dengan mengukur larutan standar $\mathrm{AB}$ dan $\mathrm{AS}$ dengan konsentrasi masing-masing 5,0 $\mu \mathrm{g} / \mathrm{mL}$ dan 7,5 $\mu \mathrm{g} / \mathrm{mL}$. Masing-masing serapan larutan dibaca pada rentang panjang gelombang 200-400 $\mathrm{nm}$ dengan spektrofotometer UV kemudian dibuat kurva antara panjang gelombang dan absorbansi yang terukur.

\subsubsection{Pembuatan training set dan test set}

Sebanyak 16 seri larutan campuran standar digunakan pada training set dan 10 seri pada test set dengan konsentrasi 2,0-8,0 $\mu \mathrm{g} / \mathrm{mL}$ untuk $\mathrm{AB}$ dan 3,0-12,0 $\mu \mathrm{g} / \mathrm{mL}$ untuk AS yang disajikan pada Tabel 1. Komposisi masing-masing senyawa pada training set ditentukan menggunakan central composite design (CCD) dua faktor $(\mathrm{k}=2)$ $[11,12]$ dan test set dipilih secara acak dengan komposisi konsentrasi senyawa standar yang belum terdapat dalam training set.

\subsubsection{Pengembangan model kemometrika}

Model kemometrika PCR dan PLS-1 dibuat menggunakan software Unscrambler ${ }^{\circledR}$ berdasarkan data absorbansi training set. Dalam pembuatan model ini dilakukan pemilihan panjang gelombang dan principal component (PC) dengan cara mengevaluasi hasil dari validasi model secara internal dan eksternal. Panjang gelombang dan PC yang dipilih adalah yang menunjukkan nilai kesalahan terkecil, recovery dan \%RSD yang dapat diterima.

Model yang didapatkan divalidasi secara internal menggunakan training set, dan secara eksternal menggunakan test set. Metode leave one out-cross validation (LOO-CV) digunakan sebagai validasi internal menggunakan software Unscrambler $^{\circledR}$ [13]. Parameter statistik seperti root mean squares error of calibration (RMSEC), root mean squares error of prediction (RMSEP), dan koefisien determinasi $\left(r^{2}\right)$ dievaluasi untuk melihat kemampuan model kemometrika dalam memprediksi hasil analisis [14]. Sedangkan 
validasi eksternal dilakukan dengan menghitung rata-rata dari recovery dan \%RSD dari hasil analisis dengan menggunakan test set.

\subsubsection{Validasi metode analisis}

Validasi metode analisis dilakukan dengan mengevaluasi parameter analisis berupa linearitas, rentang, akurasi, presisi, limit of detection (LOD), dan limit of quantification (LOQ) sesuai dengan guideline dari ICH Q2 (R1) [15]. Pengujian linearitas dan rentang analisis digunakan enam konsentrasi yang berbeda dari campuran larutan standar dengan konsentrasi 2,0-8,0 $\mu \mathrm{g} / \mathrm{mL}$ untuk $\mathrm{AB}$ dan 3,0-12,0 $\mu \mathrm{g} / \mathrm{mL}$ untuk AS. Masing-masing larutan campuran direplikasi sebanyak tiga kali kemudian diukur absorbansinya dengan spektrofotometer dan data yang dihasilkan diolah menggunakan model kemometrika yang optimum. Linearitas dievaluasi berdasarkan nilai R2 menggunakan metode regresi linear antara konsentrasi yang ditambahkan dan konsentrasi yang diprediksi oleh model kemometrika. Uji akurasi dan presisi dilakukan dengan metode standar adisi menggunakan tiga level konsentrasi, yaitu $75 \%, 100 \%$, dan $125 \%$, dari campuran larutan standar yang ditambahkan pada larutan sampel. Konsentrasi larutan yang ditambahkan berturutturut, yaitu 3,0;4,0; dan 5,0 $\mu \mathrm{g} / \mathrm{mL}$. Masing-masing level konsentrasi diukur nilai absorbansinya dengan spektrofotometer UV dan data yang diperoleh diolah dengan menggunakan model kemometrika sehingga kadar masing-masing senyawa dapat dihitung atau diprediksi. Kadar AB dan AS yang terukur dibandingkan dengan kadar yang ditambahkan pada sampel serta dihitung nilai rata-rata recovery dari metode tersebut. Uji Presisi dilakukan menggunakan konsentrasi yang sama pada pengujian akurasi. Parameter presisi yang dievaluasi berupa intra-day dan inter-day. Presisi diukur pada hari yang sama untuk intraday dan pada tiga hari yang berbeda untuk interday. Pengujian presisi dievaluasi berdasarkan nilai \% RSD kadar yang terukur. LOD dan LOQ ditentukan berdasarkan data kurva linearitas dan simpangan baku residual pada garis regresi atau y-intersep dari garis regresi yang diperoleh.

\subsubsection{Aplikasi pada sampel sediaan Iarutan}

Model PCR dan PLS-1 yang sudah dioptimasi dan divalidasi selanjutnya diaplikasikan untuk mengukur $A B$ dan $A S$ dalam sediaan farmasi berupa sediaan larutan. Jumlah sampel sediaan larutan yang digunakan adalah sebanyak lima buah sampel dengan nomor batch yang sama. Masing-masing sampel sediaan larutan diambil 0,25 $\mathrm{mL}$ kemudian dimasukkan ke dalam labu ukur $25 \mathrm{~mL}$, ditambahkan $\mathrm{HCl}$ 0,1 N hingga tanda batas, kemudian dilarutkan hingga homogen. Sampel kemudian diencerkan hingga 10.000 kali dengan menggunakan $\mathrm{HCl}$ 0,1 N. Setiap sampel dilakukan pengukuran dengan replikasi sebanyak tiga kali. Nilai absorbansi yang diukur dengan spektrofotometer pada panjang gelombang yang dipilih ditentukan dengan model kemometrika yang dikembangkan. Kadar yang terukur kemudian dibandingkan dengan kadar yang tercantum pada label.

\section{Hasil dan pembahasan}

\subsection{Profil serapan UV asam benzoat dan asam salisilat}

AB menyerap sinar UV secara maksimal pada panjang gelombang $230 \mathrm{~nm}$ sedangkan AS pada panjang gelombang $237 \mathrm{~nm}$ [16]. AB dan AS memiliki serapan UV yang tumpang tindih pada daerah panjang gelombang UV, seperti ditunjukkan pada Gambar 2. Hal tersebut menyebabkan campuran kedua senyawa tersebut tidak dapat dianalisis secara simultan dengan menggunakan metode kalibrasi univariat.

Spektrofotometri dengan pendekatan kemometrika telah digunakan secara luas untuk analisis senyawa dalam sediaan diantaranya adalah analisis empagliflozin dan metformin yang dikombinasikan dalam tablet [17]. Kedua penelitian tersebut membuktikan bahwa kalibrasi multivariat dapat digunakan dalam analisis dua senyawa secara simultan yang memiliki pro- 


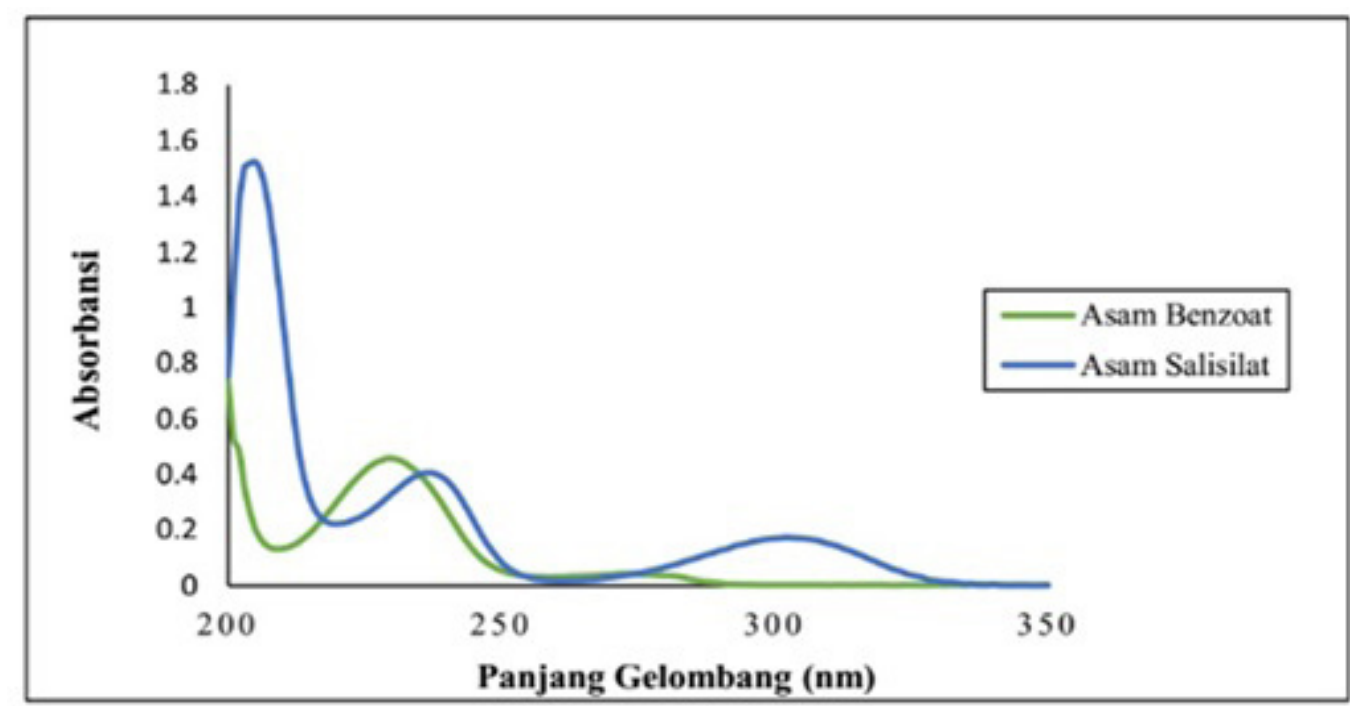

Gambar 2. Profil serapan UV asam benzoat $(5,0 \mu \mathrm{g} / \mathrm{mL})$ dan asam salisilat $(7,5 \mu \mathrm{g} / \mathrm{mL})$ yang diukur dengan spektrofotometer

fil spektra yang tumpang tindih dalam sediaan kombinasi.

\subsection{Pengembangan model kemometrika}

Optimasi dan validasi model kemometrika PCR dan PLS-1 dilakukan menggunakan rentang panjang gelombang $\mathrm{AB}$ dan $\mathrm{AS}$ antara 200$350 \mathrm{~nm}$. PCR dan PLS-1 merupakan metode analisis multivariat dan banyak digunakan dalam pengolahan data spektrofotometri yang memiliki spektra yang saling tumpang tindih [18]. Rentang panjang gelombang tersebut didapatkan jumlah PC yang direkomendasikan oleh program Unscrambler $^{\circledR}$. Jumlah PC yang direkomendasikan tersebut digunakan untuk memilih panjang gelombang yang sesuai dalam membangun model kemometrika. Rentang panjang gelombang yang digunakan dan diolah dengan program kemudian dibandingkan dan dievalusi nilai rata-rata prediksi model berupa nilai recovery dan \% RSD dari data training set dan test set. Hasil pengolahan tersebut didapatkan panjang gelombang terpilih untuk $\mathrm{AB}$ adalah 225-235 nm sedangkan AS adalah 235-245 nm. Pemilihan PC dilakukan menggunakan LOO-CV dan didapatkan PC optimum yang digunakan pada pengukuran $\mathrm{AB}$ dan AS dengan model PCR adalah 1 dan 3 sedangkan model PLS-1 adalah 2 dan 4. Parameter statistik model juga dievaluasi untuk menentukan model yang optimal (Tabel 2). Rata-rata recovery test set yang didapatkan dengan model PCR berkisar antara 98,29\% pada AB dan 100,90\% pada AS sedangkan dengan menggunakan model PLS-1 berkisar antara 98,97\% pada AB dan $101,15 \%$ pada AS (Tabel 3). Rata-rata recovery dan nilai \% RSD pengukuran test set untuk AS dengan model kemometrika dari asam benzoat yang diprediksi mendapatkan hasil lebih baik dari $\mathrm{AB}$, hal tersebut menunjukkan bahwa hasil prediksi model yang lebih baik pada pengukuran AS. Hal ini disebabkan karena konsentrasi asam benzoat yang digunakan lebih kecil dibandingkan dengan asam salisilat sehingga menyebabkan spektra UV asam benzoat tertutup oleh spektra asam salisilat (Gambar 1) tetapi model tersebut masih dapat diaplikasikan untuk campuran yang memiliki spektra UV yang sebagiannya overlapping [19].

\subsection{Validasi metode analisis}

Linearitas metode analisis yang dievaluasi menggunakan nilai koefisien korelasi (R2) untuk model PCR dan PLS-1 disajikan pada Gambar 3. Nilai R2 untuk pengukuran $A B$ dan AS dengan kedua model kemometrika menunjukkan nilai lebih dari 0,9. Hasil tersebut dapat dinyatakan 
Tabel 2. Hasil evaluasi parameter statistika model PCR dan PLS -1

\begin{tabular}{lllll}
\hline Parameter & PCR & \multicolumn{3}{c}{ PLS-1 } \\
\cline { 2 - 5 } & AB & AS & AB & AS \\
\hline$\lambda(\mathrm{nm})$ & $225-235$ & $235-245$ & $225-235$ & $235-245$ \\
PC & 1 & 3 & 2 & 4 \\
RM SEC & 0,892 & 0,141 & 0,848 & 0,088 \\
RM SEP & 1,33 & 0,20 & 1,223 & 0,147 \\
r $^{2}$ model & 0,469 & 0,996 & 0,522 & 0,998 \\
\hline
\end{tabular}

Tabel 3. Nilai recovery dari pengukuran set menggunakan model PCR dan PLS-1

\begin{tabular}{lllll}
\hline \multirow{2}{*}{$\begin{array}{l}\text { Carutan } \\
\text { Campuran }\end{array}$} & \multicolumn{3}{l}{ Recovery (\%) } & PLS-1 \\
\cline { 2 - 5 } & PCR & AS & AB & AS \\
\cline { 2 - 5 } & AB & 100,02 & 73,68 & 104,04 \\
1 & 69,49 & 107,82 & 87,45 & 107,61 \\
3 & 80,27 & 101,96 & 98,07 & 102,61 \\
4 & 95,08 & 99,29 & 78,70 & 99,15 \\
5 & 73,94 & 100,44 & 80,87 & 99,97 \\
6 & 76,28 & 101,47 & 99,72 & 100,67 \\
7 & 103,24 & 102,83 & 108,49 & 103,22 \\
8 & 105,12 & 102,60 & 157,13 & 102,55 \\
9 & 160,99 & 94,83 & 133,97 & 94,38 \\
10 & 143,23 & 97,69 & 71,62 & 97,37 \\
\hline Rata-rata & 75,28 & 100,90 & 98,97 & 101,15 \\
$\%$ RSD & 98,29 & 3,41 & 28,10 & 3,67 \\
\hline
\end{tabular}

terdapat hubungan yang linear atau proporsional antara masing-masing konsentrasi $\mathrm{AB}$ dan $\mathrm{AS}$ yang diukur dengan respon yang diprediksi oleh model.

Hasil penentuan akurasi dan presisi baik intraday maupun interday ditunjukkan pada Tabel 4. Nilai rata-rata recovery yang menggambarkan tingkat akurasi metode analisis dan presisi baik intraday maupun interday untuk AS lebih baik dibandingkan dengan hasil pengukuran untuk AB baik untuk model PCR maupun PLS-1. Nilai LOQ dan LOD dihitung berdasarkan data kurva baku dan simpangan baku residual pada garis regresi linear yang diperoleh. Perhitungan nilai LOD secara berurutan untuk $A B$ dan $A S$ pada model PCR $0,92 \mu \mathrm{g} / \mathrm{mL}$ dan $1,09 \mu \mathrm{g} / \mathrm{mL}$ dan pada model PLS- 1 adalah $1,02 \mu \mathrm{g} / \mathrm{mL}$ dan $1,13 \mu \mathrm{g} / \mathrm{mL}$. Sedangkan untuk nilai LOQ pengukuran $\mathrm{AB}$ dan AS masing-masing sebesar $2,79 \mu \mathrm{g} / \mathrm{mL}$ dan 3,31 $\mu \mathrm{g} / \mathrm{mL}$ pada model PCR dan $3,10 \mu \mathrm{g} / \mathrm{mL}$ dan 3,42 $\mu \mathrm{g} / \mathrm{mL}$ pada model PCR.

\subsection{Aplikasi metode pada sampel sediaan larutan}

Penetapan kadar $\mathrm{AB}$ dan AS dalam sampel sediaan larutan menggunakan metode spektrofotometri dengan pendekatan kemometrika PCR dan PLS-1 pada panjang gelombang 225-235 nm untuk AB dan 235-245 nm untuk AS. Komposisi AB dan AS yang diklaim pada label sediaan larutan masing-masing adalah 4\%. Hasil pengukuran kadar kedua senyawa tersebut dengan replikasi 

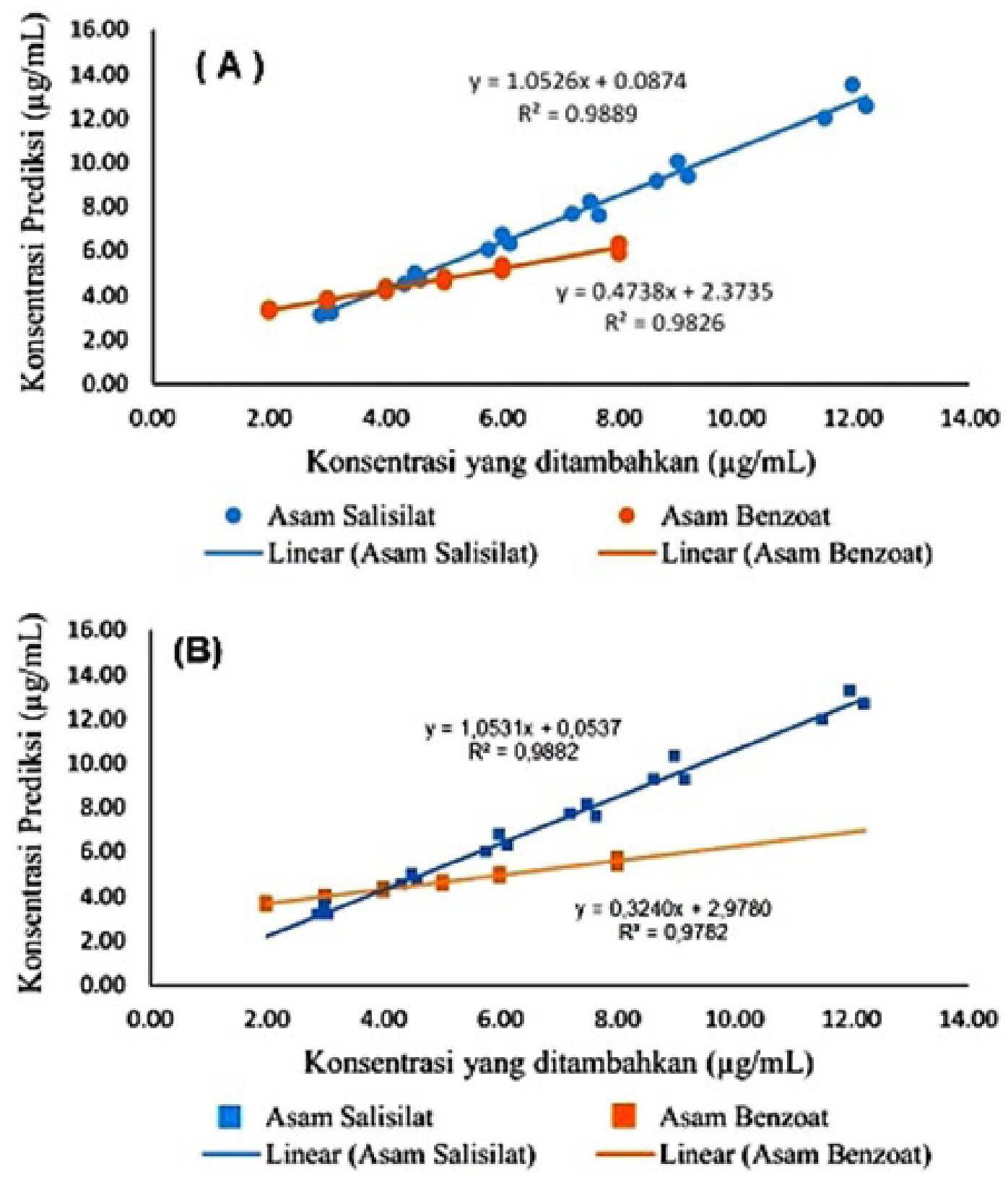

Gambar 3. Kurva linearitas pengukuran AB dan AS dengan menggunakan model (A) PCR dan (B) PLS-1

sebanyak tiga kali untuk masing-masing sampel ditunjukkan pada Tabel 5. Hasil dari \% rata-rata klaim label dalam sediaan larutan tersebut cukup bervariasi namu masih memenuhi persyaratan dalam Farmakope Indonesia Edisi V [20] yang menyatakan bahwa kadar masing-masing senyawa tidak kurang dari 90,0\% dan tidak lebih dari 110,0\%. Metode ini juga memberikan hasil prediksi pada pengulangan yang baik dengan nilai \% RSD $<2$. Hal tersebut membuktikan bahwa metode spektrofotometri dengan pendekatan kemometrika PCR dan PLS-1 dapat diaplikasikan untuk analisis $\mathrm{AB}$ dan $\mathrm{AS}$ secara simultan dalam sediaan larutan tanpa memerlukan pemisahan kedua senyawa tersebut terlebih dahulu sebelum diukur dengan spektrofotometer.

\section{Kesimpulan}

Metode spektrofotometri UV dengan pendekatan kemometrika PCR dan PLS-1 dapat digunakan untuk penetapan kadar asam benzoat dan salisilat secara simultan dalam sediaan larutan dengan panjang gelombang optimum untuk $\mathrm{AB}$ dan $\mathrm{AS}$ berturut-turut adalah 225-235 nm dan 235-245 
Tabel 4. Hasil pengukuran akurasi dan presisi dari AB dan AS

\begin{tabular}{|c|c|c|c|c|c|c|c|c|}
\hline \multirow[t]{4}{*}{ Sampel } & \multicolumn{8}{|c|}{ Recovery (\%) } \\
\hline & \multicolumn{4}{|c|}{ Intra-day } & \multicolumn{4}{|c|}{ Inter-day } \\
\hline & \multicolumn{2}{|c|}{ PCR } & \multicolumn{2}{|l|}{ PLS-1 } & \multicolumn{2}{|c|}{ PCR } & \multicolumn{2}{|l|}{ PLS-1 } \\
\hline & $\mathbf{A B}$ & AS & $\mathrm{AB}$ & AS & $\mathbf{A B}$ & AS & $\mathbf{A B}$ & AS \\
\hline \multicolumn{9}{|l|}{$(75 \%)$} \\
\hline 1 & 42,36 & 100,76 & 29,05 & 99,84 & 35,48 & 101,16 & 26,98 & 101,79 \\
\hline 2 & 39,16 & 112,07 & 29,91 & 111,08 & 34,84 & 102,37 & 24,79 & 103,39 \\
\hline 3 & 37,29 & 106,52 & 28,87 & 106,96 & 36,90 & 96,28 & 28,71 & 96,15 \\
\hline $\bar{x}$ & 39,60 & 106,45 & 29,28 & 105,96 & 35,74 & 99,60 & 26,83 & 100,44 \\
\hline$\%$ RSD & 6,46 & 5,31 & 1,91 & 5,37 & 2,95 & 3,81 & 7,32 & 3,79 \\
\hline \multicolumn{9}{|l|}{ (100\%) } \\
\hline 1 & 41,65 & 100,26 & 29,14 & 102,75 & 35,89 & 102,33 & 26,82 & 102,04 \\
\hline 2 & 38,89 & 110,32 & 29,65 & 107,10 & 34,60 & 97,91 & 24,29 & 99,97 \\
\hline 3 & 37,25 & 106,35 & 28,23 & 105,91 & 36,52 & 94,05 & 28,43 & 96,14 \\
\hline $\bar{x}$ & 39,26 & 105,64 & 29,01 & 105,25 & 35,67 & 98,10 & 26,51 & 99,38 \\
\hline$\%$ RSD & 5,66 & 4,80 & 2,49 & 2,14 & 2,75 & 4,22 & 7,85 & 3,01 \\
\hline \multicolumn{9}{|l|}{ (125\%) } \\
\hline 1 & 41,74 & 107,59 & 29,33 & 110,03 & 35,15 & 100,49 & 26,24 & 100,83 \\
\hline 2 & 38,82 & 104,54 & 28,29 & 105,69 & 37,54 & 93,87 & 23,55 & 95,83 \\
\hline 3 & 36,24 & 103,71 & 27,37 & 103,93 & 36,76 & 96,10 & 28,57 & 95,95 \\
\hline $\bar{x}$ & 38,93 & 105,28 & 28,33 & 106.55 & 36,48 & 96,82 & 26,12 & 97,54 \\
\hline$\%$ RSD & 7,07 & 1,94 & 3,46 & 2,94 & 3,35 & 3,48 & 9,63 & 2,93 \\
\hline
\end{tabular}

Tabel 5. Hasil uji aplikasi pada sampel sediaan larutan yang mengandung AB dan AS

\begin{tabular}{lllll}
\hline Sampel & \multicolumn{3}{l}{ Klaim Label $(\% \pm$ RSD) } \\
\cline { 2 - 5 } & PCR & AS & ABS-1 & AS \\
\cline { 2 - 5 } & AB & $92,34 \pm 1,40$ & $92,20 \pm 1,21$ & $110,66 \pm 0,35$ \\
1 & $100,33 \pm 0,53$ & $101,59 \pm 1,04$ & $102,32 \pm 1,26$ & $114,41 \pm 0,25$ \\
3 & $104,33 \pm 0,26$ & $94,75 \pm 1,96$ & $95,99 \pm 1,82$ & $112,13 \pm 0,20$ \\
4 & $101,48 \pm 0,16$ & $96,26 \pm 0,47$ & $98,26 \pm 0,91$ & $112,79 \pm 0,47$ \\
5 & $102,46 \pm 0,29$ & $90,99 \pm 1,25$ & $92,61 \pm 2,15$ & $109,97 \pm 0,50$ \\
\hline
\end{tabular}

nm. Principal components (PCs) yang digunakan pada pengukuran AB dan AS dengan model PCR adalah 1 dan 3 sedangkan model PLS-1 adalah 2 dan 4. Metode yang dikembangkan telah divalidasi dan dapat diaplikasikan untuk mengukur $\mathrm{AB}$ dan AS secara simultan pada sediaan larutan yang mengandung kedua senyawa tersebut.

\section{Ucapan terima kasih}

Ucapan terima kasih disampaikan kepada Laboratorium Kimia Farmasi, Jurusan Farmasi, Fakultas Ilmu Kesehatan dan Laboratorium Kimia Anorganik, Fakultas MIPA, Universitas Jenderal Soedirman atas dukungan fasilitas dan sarana prasarana penelitian. 


\section{Daftar pustaka}

1. WHO Model Prescribing Information: Drugs Used in Skin Diseases: Antifugal drugs: Benzoic acid + salicylic acid (Whitfield's ointment) [Internet]. [cited 2017 Jun 6]. Available from: http://apps. who.int/medicinedocs/en/d/Jh2918e/24.2.html

2. Mikami E, Goto T, Ohno T, Matsumoto H, Nishida M. Simultaneous analysis of dehydroacetic acid, benzoic acid, sorbic acid and salicylic acid in cosmetic products by solid-phase extraction and high-performance liquid chromatography.J Pharm Biomed Anal. 2002;28(2):261-7.

3. Ahmad I, Vaid FH. Determination of benzoic acid and salicylic acid in commercial benzoic and salicylic acids ointments by spectrophotometric method. PakJ Pharm Sci. 2009;22(1):18-22.

4. Silva BO. First derivative spectrophotometric and high performance liquid chromatographic simultaneous determination of benzoic and salicylic acids in pharmaceutical preparations. Niger Q J Hosp Med. 2008;18(2):92-5.

5. Morishita M, Iizuka $H$, Katayanagi M, Yajima T. Application of steam carrier gas chromatography to analyses of pharmaceuticals; I. Determination of salicylic acid and phenol in pharmaceutical preparations in the Japanese Pharmacopoeia X. Bunseki Kagaku. 1986;35(3):193-7.

6. Driouich R, Takayanagi T, Oshima M, Motomizu S. Separation and determination of haloperidol, parabens and some of their degradation products by micellar electrokinetic chromatography. $J$ Chromatogr A. 2000;903(1):271-8.

7. Huang H-Y, Lai Y-C, Chiu C-W, Yeh J-M. Comparing micellar electrokinetic chromatography and microemulsion electrokinetic chromatography for the analysis of preservatives in pharmaceutical and cosmetic products. J Chromatogr A. 2003;993(12):153-64.

8. Wasito H, Phechkrajang C. Validated visible spectrophotometry for quantitative analysis of pirenoxine in the presence of paraben preservatives in eye drop preparations. In: 2015 4th International Conference on Instrumentation, Communications, Information Technology, and
Biomedical Engineering (ICICI-BME). 2015. p. 327-31.

9. Phechkrajang CM, Sribunruang S, Thitipong A, Jarusintanakorn S, Sratthaphut L, Nacapricha D, et al. Chemometrics-Assisted UV Spectrophotometric Method for Determination of Acetaminophen and Chlorzoxazone in Tablets. Mahidol Univ J Pharm Sci. 2011;38 (3-4):23-33.

10. Santos PM, Pereira-Filho ER, Rodriguez-Saona LE. Rapid detection and quantification of milk adulteration using infrared microspectroscopy and chemometrics analysis. Food Chem. 2013;138(1):19-24.

11. Hopke PK. The evolution of chemometrics. Anal Chim Acta. 2003;500(1):365-77.

12. Vera Candioti L, De Zan MM, Cámara MS, Goicoechea HC. Experimental design and multiple response optimization. Using the desirability function in analytical methods development. Talanta. 2014;124:123-38.

13. Wold S, Sjöström M, Eriksson L. PLS-regression: a basic tool of chemometrics. Chemom Intell Lab Syst. 2001;58(2):109-30.

14. Faber K, Kowalski BR. Critical evaluation of two F-tests for selecting the number of factors in abstract factor analysis. Anal Chim Acta. 1997;337(1):57-71.

15. Validation of Analytical Procedures: Text and Methodology : ICH [Internet]. [cited 2017 Jun 6]. Available from: http://www.ich.org/products/ guidelines/quality/quality-single/article/ validation-of-analytical-procedures-text-andmethodology.html

16. Auterhoff, Kovar. Identifikasi Obat. Bandung: Institut Teknologi Bandung; 2002.

17. youb BM. Development and validation of simple spectrophotometric and chemometric methods for simultaneous determination of empagliflozin and metformin: Applied to recently approved pharmaceutical formulation. Spectrochim Acta A Mol Biomol Spectrosc. 2016;168:118-22.

18. El-Gindy A, Emara S, Mostafa A. Application and validation of chemometrics-assisted spectrophotometry and liquid chromatography for the simultaneous determination of six- 
component pharmaceuticals. J Pharm Biomed Anal. 2006;41(2):421-30.

19. Monakhova YB, Mushtakova SP, Kolesnikova SS, Astakhov SA. Chemometrics-assisted spectrophotometric method for simultaneous determination of vitamins in complex mixtures. Anal Bioanal Chem. 2010;397(3):1297-306.

20. Kementrian Kesehatan Republik Indonesia. Farmakope Indonesia Edisi V. 2014. 